\title{
PENGARUH KERJASAMA TIM TERHADAP UPAYA PENGURANGAN RISIKO INFEKSI DI UNIT RAWAT INAP RUMAH SAKIT
}

\author{
Cintya Elvira Purba, Natsir Nugroho dan Ratna Indrawati \\ Universitas Esa Unggul, Jakarta, Indonesia \\ Email: c_elv@yahoo.com, natsir.nugroho@esaunggul.ac.id dan \\ ratna.indrawati@esaunggul.ac.id
}

\begin{tabular}{l}
\hline ARTIKEL INFO \\
\hline Tanggal diterima: 5 April 2021 \\
Tanggal revisi: 15 April 2021 \\
Tanggal yang disetujui: 25 \\
April 2021 \\
\hline Keywords: \\
communication; \\
teamwork; leadership; reduce \\
the risk of health care- \\
associated infections
\end{tabular}

\section{ABSTRACT}

On March 11, 2020 WHO designated Covid-19 as a pandemic. In Indonesia until June 2020 according to data from PHEOC Ministry of Health, Covid-19 cases have been confirmed to have reached 56,385 cases, of which 2,976 cases died. In the era of the Covid-19 pandemic, RS X Pulomas implemented various efforts in reducing the risk of infection. This study aims to determine the influence of communication and teamwork mediated by leadership on infection risk reduction efforts in Hospital X Inpatient Unit, Pulomas. The research model used is multiple correlation, which uses quantitative approach and survey method. The variables bound in this study are Infection Risk Reduction Efforts with free variables are: Communication, Teamwork and Leadership as mediation variables. The sample in this study is a saturated sample of 60 nurses in the inpatient unit, using questionnaire instruments with Likert scale measurement. The data was analyzed using SPSS 25 and AMOS 20. The results showed that communication and teamwork had a significant effect on efforts to reduce the risk of infection. Teamwork variables are the most influential variables in efforts to reduce the risk of infection. The results of other analyses obtained by the leadership do not mediate between communication and teamwork against infection risk reduction efforts.

\begin{abstract}
ABSTRAK
Tanggal 11 Maret 2020 WHO menetapkan Covid-19 sebagai pandemik. Di Indonesia sampai dengan Juni 2020 menurut data dari PHEOC Kemenkes kasus Covid-19 terkonfirmasi sudah mencapai 56.385 kasus diantaranya 2.976 kasus meninggal dunia. Dalam era pandemic Covid-19, RS X Pulomas menerapkan berbagai upaya dalam mengurangi risiko infeksi. Penelitian ini bertujuan untuk mengetahui pengaruh komunikasi dan kerjasama tim yang dimediasi oleh kepemimpinan terhadap upaya pengurangan risiko infeksi di Unit Rawat Inap Rumah Sakit X, Pulomas. Model penelitian yang digunakan adalah korelasi multipel, dimana menggunakan pendekatan kuantitatif dan metode survey. Variabel terikat dalam penelitian ini adalah Upaya
\end{abstract}

\begin{tabular}{ll}
\hline How to cite: & Purba, Cintya Elvira, et. al. (2021) Pengaruh Kerjasama Tim Terhadap Upaya Pengurangan Risiko \\
& Infeksi Di Unit Rawat Inap Rumah Sakit. Jurnal Health Sains 2(4). \\
& http://jurnal.healthsains.co.id/index.php/jhs/article/view/145 \\
E-ISSN: & 2723-6927 \\
Published by: & Ridwan Institute
\end{tabular}




\section{Kata Kunci:}

komunikasi; kerjasama tim; kepemimpinan; upaya pengurangan risiko infeksi
Pengurangan Risiko Infeksi dengan variabel-variabel bebas adalah: Komunikasi, Kerjasama Tim dan Kepemimpinan sebagai variabel mediasi. Sampel dalam penelitian ini merupakan sampel jenuh yaitu sebanyak 60 perawat di unit rawat inap, menggunakan instrument kuesioner dengan pengukuran skala Likert. Data hasil penelitian dianalisis menggunakan SPSS 25 dan AMOS 20. Hasil penelitian menunjukkan bahwa, Komunikasi dan kerjasama tim berpengaruh signifikan terhadap upaya pengurangan risiko infeksi. Variabel kerjasama tim merupakan variabel yang paling berpengaruh dalam upaya pengurangan risiko infeksi. Hasil analisis lainnya didapatkan kepemimpinan tidak memediasi antara komunikasi dan kerjasama tim terhadap upaya pengurangan risiko infeksi.

\section{Pendahuluan}

Pada awal tahun 2020, World Health Organization mengumumkan wabah pneumonia baru yang bermula dari Wuhan, Provinsi Hubei yang kemudian menyebar dengan cepat ke lebih dari 190 negara dan teritori. Wabah ini diberi nama coronavirus disease 2019 (Covid-19) yang disebabkan oleh Severe Acute Respiratory Syndrome Coronavirus-2 (SARS-CoV-2) (WHO,2020)

Berdasarkan data yang didapat dari Centers for Disease Control and Prevention (CDC) sampai bulan Juni 2020, di Amerika Serikat tercatat petugas kesehatan yang terpapar Covid-19 adalah 92.572 kasus, dengan kematian sejumlah 507 kasus. Sejak kasus infeksi virus corona terdeteksi di Indonesia pada awal Maret 2020, puluhan dokter turut menjadi korban meninggal dunia akibat terpapar virus ini. Berdasarkan catatan Pengurus Besar Ikatan Dokter Indonesia (PB IDI) hingga Juni 2020, ada 32 dokter dari berbagai wilayah di Indonesia yang gugur akibat Covid-19. Muncul kekhawatiran akan terjadi penularan yang lebih besar ketika beberapa daerah di Indonesia menerapkan era kenormalan baru atau new normal.

Pelayanan kesehatan yang saat ini berpusat pada pasien (patient centered care) memerlukan lebih banyak perhatian untuk mengelola kerjasama tim dalam pelayanan kesehatan karena pelayanan kesehatan menjadi lebih kompleks. Praktek kolaboratif antar praktisi kesehatan menuntut komunikasi tingkat tinggi, pemberian dan pembagian tugas yang akurat, hasil, peran dan tanggung jawab yang sesuai (peran kepemimpinan).

Dimasa pandemi Covid-19 RS X Pulomas telah menerapkan berbagai upaya dalam meningkatkan mutu pelayanan, terutama dalam menerapkan sasaran kelima keselamatan pasien yaitu pengurangan risiko infeksi terkait pelayanan keselamatan. Upaya pengurangan risiko infeksi yang dilakukan antara lain dengan menerapkan kewaspadaan standar (universal) diantaranya hand hygiene dan penggunaan alat pelindung diri sesuai dengan area kerjanya dan kewaspadaan transmisi. Sampai dengan Juni 2020, belum ada kasus tenaga kesehatan yang terinfeksi Covid-19. Hasil supervisi Tim Pencegahan dan Pengendalian Infeksi RS X Pulomas melaporkan angka kepatuhan perawat dalam melaksanakan five moment hand hygiene pada saat awal pandemi meningkat yaitu dari $77 \%$ pada bulan Februari, meningkat menjadi 91\% pada bulan Maret 2020, namun pada bulan Mei 2020 angka tersebut turun menjadi 82\%. Hal ini menggambarkan pelaksanaan five moment hand hygiene di unit rawat inap belum berjalan konsisten. Demikian halnya dengan angka kepatuhan penggunaan alat pelindung diri (APD) dimana angka tertinggi terdapat pada bulan April 2020 yaitu 100\%, namun pada bulan Juni 2020, angka tersebut turun menjadi 
98\% (Laporan Tim Pencegahan dan Pengendalian Infeksi RS X Pulomas, 2020)

Kompetensi dalam berkomunikasi menjadi suatu hal yang penting dalam meningkatkan mutu pelayanan. Penelitian (Walshe \& Boaden, 2005) berpendapat budaya keselamatan pasien positif, meliputi komunikasi yang didasarkan pada kepercayaan dan transparansi, proses dan alur informasi yang baik, persepsi bersama tentang arti penting keselamatan pasien, dan perhatian dan pengenalan pada pentingnya kesalahan. Hasil survey Budaya Keselamatan Pasien RS $\mathrm{X}$ Pulomas yang diakukan Tim Pencegahan dan Pengendalian Infeksi tahun 2019 didapatkan pada proses serah terima masih rendah yaitu 59\% sementara angka keterbukaan komunikasi 78,9\%. Penelitian (Y. Liu et al., 2020) menyatakan bahwa transfer pasien yang tidak aman sebagian besar disebabkan oleh kesalahan petugas kesehatan terutama dalam proses hand over dan persiapan tim yang kurang baik. Proses kerjasama tim pada survey budaya keselamatan pasien rs x pulomas tahun 2019 didapatkan kerjasama tim dalam unit kerja 92\% dan kerjasama tim antar unit $86,9 \%$, hal ini berarti kerjasama tim yang terbentuk di bagian keperawatan RS X Pulomas sudah berjalan cukup baik.

Keberhasilan suatu unit dalam mencapai tujuannya, tidak terlepas dari fungsi kepala ruangan sebagai pemimpin. Kepala ruangan adalah seorang tenaga perawat professional yang diberi tanggungjawab dan wewenang dalam mengelola kegiatan pelayanan keperawatan di satu ruang rawat. Menurut (Kron \& Chiu, 1981), ruang lingkup kegiatan kepemimpinan dalam keperawatan meliputi perencanaan dan pengorganisasian, membuat penugasan dan memberikan pengarahan (Direction), pemberian bimbingan, mendorong kerjasama dan partisipatif, kegiatan koordinasi (Coordination) dan evaluasi hasil kerja. Hasil survey Budaya Keselamatan Pasien RS X
Pulomas terkait kepemimpinan, harapan dan tindakan supervisor yang mendukung keselamatan pasien memiliki nilai $87,1 \%$, artinya kepemimpinan di unit rawat inap RS X Pulomas sudah berjalan cukup baik. Namun berdasarkan wawancara dan pengamatan peneliti, kepemimpinan di RS X Pulomas pada era pandemi Covid-19 terjadi perubahan atau pergantian kepala ruang perawatan yang relatif singkat (mutasi), kurangnya intensitas pertemuan/diskusi baik dari sisi durasi pertemuan maupun frekuensi. Oleh karena itu, peneliti mengangkat kepemimpinan sebagai faktor yang memediasi antara komunikasi dan kerjasama tim terhadap upaya pengurangan risiko infeksi di RS X Pulomas, pertanyaan yang timbul adalah apakah kepemimpinan yang berjalan saat ini berjalan efektif atau tidak. Banyak peneliti yang mengkaji tentang hubungan antara komunikasi, kerjasama tim maupun kepemimpinan terhadap keselamatan pasien di rumah sakit, namun dimasa pandemi ini peneliti akan memfokuskan pada salah satu indikator keselamatan pasien yaitu upaya pengurangan risiko infeksi. Penelitian terdahulu (Susilo et al., 2020) menyatakan Ada hubungan kepemimpinan, komunikasi dan supervisi dengan implementasi keselamatan pasien oleh perawat pelaksana, namun variabel kerjasama tim dan budaya keselamatan tidak memiliki hubungan dengan implementasi keselamatan pasien oleh perawat pelaksanan. Dalam penelitian yang lain didapatkan kepemimpinan berperan penting dalam kegiatan pencegahan infeksi (Mouaze et al., 2010). Dalam penelitian ini, peneliti memfokuskan pada faktor manakah yang paling berpengaruh dalam upaya pengurangan risiko infeksi pada era pandemic COVID-19 dimana pada era new normal kita harus beradaptasi dengan beraktifitas dan bekerja sesuai protokol kesehatan yang telah ditetapkan, termasuk didalamnya pembatasan sosial (KemenKes, 2016).

Penelitian ini bertujuan untuk mengetahui pengaruh komunikasi dan 
kerjasama tim yang dimediasi oleh kepemimpinan terhadap upaya pengurangan risiko infeksi di Unit Rawat Inap Rumah Sakit X, Pulomas pada era pandemi Covid-19, sehingga dapat meningkatkan kinerja Unit dan terlaksananya pelayanan yang mengutamakan keselamatan pasien dan tenaga kesehatan di unit rawat inap terutama dalam upaya pengurangan risiko infeksi. Manfaat yang didapatkan dari penelitian ini diharapkan dapat menambah kepustakaan tentang manajemen mutu dan penerapan patient safety terutama dalam hal upaya pengurangan risiko infeksi, serta dapat memberikan kontribusi terhadap ilmu perumahsakitan khususnya mengenai keselamatan pasien di masa pandemi Covid19.

\section{Metode Penelitian}

Penelitian ini dilaksanakan di RS X yang berlokasi di Kelurahan Kayu Putih, Pulomas, Jakarta Timur. Objek yang menjadi kajian adalah seluruh perawat di Unit Rawat Inap dilaksanakan pada bulan Maret sampai dengan September 2020,

Penelitian ini menggunakan model korelasi multiple dengan pendekatan kuantitatif, metode survey, dan teknik korelasional (correlational research) yang bertujuan mengetahui hubungan atau pengaruh antara dua variabel atau lebih. Variabel terikat adalah Upaya Pengurangan Risiko Infeksi (Y) dan variabel-variabel bebas adalah: Komunikasi (X1), Kerjasama Tim (X2) dan Kepemimpinan (Z) sebagai variabel mediasi. Populasi pada penelitian ini adalah seluruh perawat di unit rawat inap RS X Pulomas sebanyak 60 orang, sampel di ambil menggunakan teknik Non Random Sampling (Sample Jenuh). Teknik pengumpulan data dalam penelitian ini menggunakan instrument berbentuk kuesioner/ angket. Analisis dalam penelitian ini dilakukan dengan menggunakan program Amos 20 untuk uji hipotesis dan normalitas serta dibantu dengan program IBM SPSS 25 untuk uji reliabilitas dan validitas.

\section{Hasil dan Pembahasan}

\section{A. Hasil Penelitian}

1. Distribusi karakteristik responden Kuesioner diedarkan dari tanggal 1 Agustus - 15 Agustus 2020. Total kuesioner yang disebarkan dalam penelitian ini berjumlah 60 kuesioner. Adapun profil responden yang berpartisipasi dalam penelitian ini ditunjukkan pada tabel 1 sebagai berikut

Tabel 1

\section{Statistik Deskripsi Sampel}

\begin{tabular}{|c|c|c|}
\hline Uraian & Frekuensi & Persentase \\
\hline \multicolumn{3}{|l|}{ Jenis Kelamin: } \\
\hline Pria & 0 & $0 \%$ \\
\hline Wanita & 60 & $100 \%$ \\
\hline Total & 60 & $100 \%$ \\
\hline \multicolumn{3}{|l|}{ Usia: } \\
\hline 20-25 tahun & 5 & $8.33 \%$ \\
\hline 26-30 tahun & 19 & $31.67 \%$ \\
\hline $31-35$ tahun & 15 & $25 \%$ \\
\hline$>35$ tahun & 21 & $35 \%$ \\
\hline Total & 60 & $100 \%$ \\
\hline \multicolumn{3}{|l|}{ Tingkat } \\
\hline D3 & 22 & $36.67 \%$ \\
\hline \multicolumn{3}{|l|}{$\mathrm{S} 1$} \\
\hline Total & 60 & $100 \%$ \\
\hline \multicolumn{3}{|l|}{ Masa Kerja } \\
\hline$<5$ tahun & 15 & $25 \%$ \\
\hline $5-10$ tahun & 33 & $55 \%$ \\
\hline $11-15$ tahun & 5 & $8.33 \%$ \\
\hline $16-20$ tahun & 2 & $3.33 \%$ \\
\hline$>20$ tahun & 5 & $8.33 \%$ \\
\hline Total & 60 & $100 \%$ \\
\hline
\end{tabular}

Sumber: Data primer diolah, 2020

Dari tabel 1 dapat dilihat gambaran tentang jenis kelamin, tingkat pendidikan, dan masa kerja responden. Jika dilihat dari jenis kelamin responden $100 \%$ responden adalah perempuan. Dari tingkat pendidikan, mayoritas pendidikan perawat di unit rawat inap adalah D3 Keperawatan, yaitu sebanyak 38 orang $(63,33 \%)$. 
Dari sisi masa kerja, sebagian besar responden memiliki masa kerja lebih dari 5-10 tahun yaitu sebanyak 33 orang (55\%). Hal ini menunjukkan bahwa responden memiliki cukup pengalaman, sehingga responden telah mengetahui dengan baik untuk kondisi dan situasi di unit rawat inap RS $\mathrm{X}$ Pulomas.

Deskripsi variabel digunakan untuk mengetahui pengaruh komunikasi dan kerjasama tim terhadap upaya pengurangan risiko infeksi, dengan kepemimpinan sebagai variabel mediasi untuk mendapatkan kecenderungan jawaban responden terhadap masingmasing variabel, maka akan didasarkan pada nilai skor rata-rata (indeks) yang dikatagorikan ke dalam rentang skor berdasarkan perhitungan three box method (Ferdinand, 2008). Dari analisis deskriptif yang dilakukan terhadap seluruh variabel penelitian diatas, maka dilakukan rekapitulasi hasil sebagai berikut:

Tabel 2

\section{Rekapitulasi Statistik Deskriptif Variabel Peneliti}

\begin{tabular}{|c|c|c|c|c|}
\hline & Variabel & Jumlah & Indeks & Kategori \\
\hline \multirow[t]{3}{*}{1} & $\begin{array}{l}\text { Upaya } \\
\text { Pengurangan } \\
\text { Risiko Infeksi }\end{array}$ & 227 & 56.75 & $\begin{array}{l}\text { Baik } \\
\text { Sekali }\end{array}$ \\
\hline & $\begin{array}{l}\text { - Kewaspadaan } \\
\text { Standar }\end{array}$ & 226 & 56.50 & $\begin{array}{l}\text { Baik } \\
\text { Sekali }\end{array}$ \\
\hline & $\begin{array}{l}\text { - Kewaspadaan } \\
\text { Transmisi }\end{array}$ & 229 & 57.25 & $\begin{array}{l}\text { Baik } \\
\text { Sekali }\end{array}$ \\
\hline \multirow[t]{4}{*}{2} & Komunikasi & 204 & 51 & $\begin{array}{l}\text { Baik } \\
\text { Sekali }\end{array}$ \\
\hline & $\begin{array}{l}\text { - Kepercayaan } \\
\text { dan } \\
\text { Keterbukaan }\end{array}$ & 204 & 51.00 & $\begin{array}{l}\text { Baik } \\
\text { Sekali }\end{array}$ \\
\hline & $\begin{array}{r}\text { - Proses dan } \\
\text { Informasi }\end{array}$ & $\begin{array}{c}201 . \\
5\end{array}$ & 50.38 & $\begin{array}{l}\text { Baik } \\
\text { Sekali }\end{array}$ \\
\hline & $\begin{array}{c}\text { - Perhatian dan } \\
\text { Pengenalan } \\
\text { Pentingnya } \\
\text { Keselamatan }\end{array}$ & $\begin{array}{c}205 . \\
67\end{array}$ & 51.42 & $\begin{array}{l}\text { Baik } \\
\text { Sekali }\end{array}$ \\
\hline 3 & Kerjasama Tim & $\begin{array}{c}195 . \\
8\end{array}$ & 48.95 & $\begin{array}{l}\text { Baik } \\
\text { Sekali }\end{array}$ \\
\hline & $\begin{array}{l}\text { - Komitmen } \\
\text { pada Tujuan }\end{array}$ & 200 & 50.00 & $\begin{array}{l}\text { Baik } \\
\text { Sekali }\end{array}$ \\
\hline
\end{tabular}

\begin{tabular}{|c|c|c|c|c|}
\hline & $\begin{array}{l}\text { - Komunikasi } \\
\text { Ide dan } \\
\text { Gagasan } \\
\end{array}$ & 189 & 47.25 & $\begin{array}{l}\text { Baik } \\
\text { Sekali }\end{array}$ \\
\hline & $\begin{array}{c}\text { - Efektifitas } \\
\text { Personal }\end{array}$ & 201 & 50.25 & $\begin{array}{l}\text { Baik } \\
\text { Sekali }\end{array}$ \\
\hline 4 & Kepemimpinan & $\begin{array}{c}191 . \\
5\end{array}$ & 47.88 & $\begin{array}{l}\text { Baik } \\
\text { Sekali }\end{array}$ \\
\hline & - Supervisi & $\begin{array}{c}190 . \\
25\end{array}$ & 47.56 & $\begin{array}{l}\text { Baik } \\
\text { Sekali }\end{array}$ \\
\hline & - Pengarahan & $\begin{array}{c}191 . \\
33\end{array}$ & 47.83 & $\begin{array}{l}\text { Baik } \\
\text { Sekali }\end{array}$ \\
\hline & $\begin{array}{l}\text { - Koordinasi } \\
\text { dan } \\
\text { Kolaborasi }\end{array}$ & $\begin{array}{c}193 . \\
33\end{array}$ & 48.33 & $\begin{array}{l}\text { Baik } \\
\text { Sekali }\end{array}$ \\
\hline
\end{tabular}

Sumber data Primer yang telah diolah data 2020

Berdasarkan data diatas didapatkan nilai indeks paling tinggi terdapat pada variabel upaya pengurangan risiko infeksi dengan nilai 56,75 dan indeks terendah pada variabel kepemimpinan dengan nilai 47,88. Dari nilai indeks indikator tertinggi terdapat pada pengetahuan tentang kewaspadaan transmisi pada variabel upaya pengurangan risiko infeksi dengan angka 57,25 dan nilai indeks terendah pada indikator komunikasi ide dan gagasan pada variabel kerjasama tim dengan angka 47,25.

Dalam penelitian ini, digambarkan model path dari 60 responden, sehingga diperoleh model analisis jalur untuk dibangun path diagram. Path diagram ini sangat memudahkan untuk melihat hubungan kausalitas yang akan diuji. Adapun bentuk Path diagram hasil olahan data lewat Amos didapatkan hasil seperti pada gambar 1 .

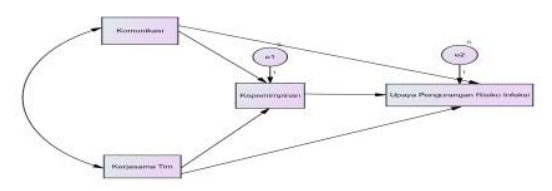

Sumber: Hasil penelitian yang diolah menggunakan SEM-AMOS 20, 2020.

Gambar 1

Path Diagram Model Utama Penelitian 
Berdasarkan gambar path diagram di atas, dapat diturunkan dalam bentuk tabel Regression weights dan hubungan antar variabel seperti pada tabel 3 dan tabel 4 dibawah ini.

Tabel 3

\begin{tabular}{|c|c|c|c|c|}
\hline \multicolumn{5}{|c|}{ Regression Weight } \\
\hline & & Estim & e SE & $\mathrm{CR}$ \\
\hline Kepemimpinan & $\leftarrow$ Komunikasi & 889 & 150 & $5,913 * * *$ \\
\hline Kepemimpinan & $\leftarrow \begin{array}{l}\text { Kerjasama } \\
\text { Tim }\end{array}$ & 613 & 180 & $3,405^{* * *}$ \\
\hline $\begin{array}{l}\text { Upaya } \\
\text { pengurangan } \\
\text { risiko infeksi }\end{array}$ & $\leftarrow$ Komunikasi & 162 & 061 & 2,638008 \\
\hline $\begin{array}{l}\text { Upaya } \\
\text { pengurangan } \\
\text { risiko infeksi }\end{array}$ & $\leftarrow \begin{array}{c}\text { Kerjasama } \\
\text { Tim }\end{array}$ & 522 & 064 & $8,192 * * *$ \\
\hline $\begin{array}{l}\text { Upaya } \\
\text { pengurangan } \\
\text { risiko infeksi }\end{array}$ & $\leftarrow$ Kepemimpina & a 151 & 042 & $3,578 * * *$ \\
\hline
\end{tabular}

Nilai CR menunjukkan nilai critical ratio yang didapatkan dari nilai estimasi yang dibagi oleh standard errornya (SE). Semakin tinggi nilai CR semakin tinggi nilai signifikansi. Pada tabel diatas diperoleh bahwa hubungan pengaruh yang paling signifikan atau memiliki nilai $\mathrm{CR}$ yang paling besar adalah pengaruh antara kerjasama tim terhadap upaya pengurangan risiko infeksi dengan nilai CR 8,192.

Berdasarkan analisis diatas diperoleh nilai $\mathrm{P}$ yang menunjukkan $* * *$ dimana memiliki nilai 0.000 dan nilai $P$ 0,008 , kedua nilai tersebut lebih kecil dari nilai $\alpha=0,05$, maka disimpulkan bahwa setiap variabel mempunyai hubungan yang signifikan.

Tabel 4

\begin{tabular}{|c|c|c|}
\hline Variabel & Koefisien & $\begin{array}{c}\text { Sifat } \\
\text { Hubungan }\end{array}$ \\
\hline $\begin{array}{l}\text { Komunikasi } \\
\text { terhadap } \\
\text { Kepemimpinan }\end{array}$ & 0,89 & Langsung \\
\hline $\begin{array}{l}\text { Kerjasama Tim } \\
\text { terhadap } \\
\text { Kepemimpinan }\end{array}$ & 0,61 & Langsung \\
\hline $\begin{array}{l}\text { Kepemimpinan } \\
\text { terhadap Upaya }\end{array}$ & $-0,15$ & Langsung \\
\hline
\end{tabular}

\begin{tabular}{|c|c|c|}
\hline $\begin{array}{l}\text { pengurangan } \\
\text { risiko infeksi }\end{array}$ & & \\
\hline $\begin{array}{l}\text { Komunikasi } \\
\text { terhadap Upaya } \\
\text { pengurangan } \\
\text { risiko infeksi }\end{array}$ & 0,16 & Langsung \\
\hline $\begin{array}{l}\text { Kerjasama tim } \\
\text { terhadap upaya } \\
\text { pengurangan } \\
\text { infeksi }\end{array}$ & 0,52 & Langsung \\
\hline $\begin{array}{l}\text { Komunikasi } \\
\text { terhadap Upaya } \\
\text { pengurangan } \\
\text { risiko infeksi } \\
\text { melalui } \\
\text { Kepemimpinan }\end{array}$ & $-0,134$ & $\begin{array}{l}\text { Tidak } \\
\text { langsung }\end{array}$ \\
\hline $\begin{array}{l}\text { Kerjasama tim } \\
\text { terhadap upaya } \\
\text { pengurangan } \\
\text { infeksi melalui } \\
\text { kepemimpinan }\end{array}$ & $-0,92$ & $\begin{array}{l}\text { Tidak } \\
\text { langsung }\end{array}$ \\
\hline
\end{tabular}

Sumber: data yang diolah, 2020

Berdasarkan path diagram hasil pengolahan data dengan menggunakan program AMOS, maka dapat dilakukan untuk membentuk persamaaan dan estimasi. Setelah estimasi dan persamaaan terbentuk maka dilakukan uji goodness of fit test (kesesuaian model) dan uji hipotesa. Dari hasil pengolahan data dan kriteria penerimaan pengujian goodness of fit test model berdasarkan ukuran kecocokan absolut yang menentukan derajat prediksi model keseluruhan (model struktural pengukuran) terhadap matrik korelasi dan kovarian adalah baik karena nilai chi square yang diperoleh 0.000 dimana nilai ideal sebesar < 3, semakin kecil nilai chi square maka semakin cocok model tersebut. Selanjutnya berdasarkan ukuran kecocokan inkremental yaitu membandingkan model yang diusulkan dengan model dasar (baseline model) juga sangat baik karena Normed Fit Index (NFI) bernilai 1,000 atau biasa disebut good fit. Sehingga secara keseluruhan model persamaan analisis jalur yang digunakan dapat diterima dan 
pengujian hipotesa dapat dilanjutkan Pengujian hipotesa dilakukan dengan menganalisis signifikansi besaran regression weight. Analisis ini dilakukan untuk menunjukan besaran dari efek menyeluruh (total effect), efek langsung (direct effect) serta efek tidak langsung (indirect effect) dari satu variabel terhadap variabel lainnya. Adapun yang dijadikan dasar pengambilan keputusan uji signifikansi atas regresión weight adalah :

1. Jika p-value < alpha 0,05 maka hipotesa menjadi nol (0) dan $\mathrm{H} 0$ ditolak artinya ada pengarujh antara dua variabel secara statistik.

2. Jika p-value $>$ alpha 0,05 maka hipotesa menjadi nol (0) dan $\mathrm{H} 0$ diterima artinya tidak ada pengaruh antara dua variabel secara statistik.

Berikut ini tabel rangkuman analisis path, dimana hasil pengolahan dengan program AMOS tersebut diperoleh nilai hasil regression weight.

Tabel 5

\section{Hasil Regression Weight}

\begin{tabular}{|c|c|c|c|c|}
\hline Pengaruh Langsung & $\begin{array}{l}\text { Koefisien } \\
\text { Jalur }\end{array}$ & $\overline{\text { SE }}$ & $\begin{array}{l}P \\
\text { Value }\end{array}$ & $\begin{array}{l}\mathbf{R} \\
\text { Square }\end{array}$ \\
\hline $\begin{array}{l}\text { Komunikasi terhadap } \\
\text { kepemimpinan }\end{array}$ & 0.889 & 0.150 & $* * *$ & \multirow[b]{2}{*}{0.640} \\
\hline $\begin{array}{l}\text { Kerjasama tim } \\
\text { terhadap } \\
\text { kepemimpinan }\end{array}$ & .613 & 0.180 & $* * *$ & \\
\hline $\begin{array}{l}\text { Kepemimpinan } \\
\text { terhadap upaya } \\
\text { pengurangan risiko } \\
\text { infeksi }\end{array}$ & -0.151 & 0.42 & $* * *$ & \multirow{3}{*}{0.634} \\
\hline $\begin{array}{l}\text { Komunikasi terhadap } \\
\text { upaya pengurangan } \\
\text { risiko infeksi }\end{array}$ & 0.162 & 0.61 & 0.008 & \\
\hline $\begin{array}{l}\text { Kerjasama tim } \\
\text { terhadap upaya } \\
\text { pengurangan risiko } \\
\text { infeksi }\end{array}$ & 0.522 & 0.64 & $* * *$ & \\
\hline \multirow{2}{*}{\multicolumn{5}{|c|}{$\begin{array}{l}* * * \text { (artinya nilai } \mathrm{P} \text {-value }<0,001 \\
\text { sama saja sudah }<0,05, \text { signifikan })\end{array}$}} \\
\hline & & & & \\
\hline Sumber: & ut put & MC & 20,20 & 20 \\
\hline
\end{tabular}

Berdasarkan hasil tersebut
diketahui bahwa yang memiliki
pengaruh langsung paling besar
terhadap upaya pengurangan risiko
infeksi di unit rawat inap RS X Pulomas

pada era pandemi covid 19 adalah variable kerjasama tim dimana memiliki pengaruh sebesar 52,2\%. Hal ini sesuai dengan pendapat yang menyatakan bahwa faktor-faktor yang menjadi tantangan bagi perawat dalam memberikan keperawatan yang aman dan memberikan kontribusi dalam keselamatan pasien salah satunya adalah kerjasama tim (Murray et al., 2004).

Pada tabel 5 diatas, dicantumkan besarnya koefisien determinasi (adjusted $R$ Square) pada variabel kepemimpinan adalah 0,640 atau $64,0 \%$. Hal ini berarti $64 \%$ variabel kepemimpinan dapat dijelaskan oleh komunikasi dan kerjasama tim, sedangkan sisanya yaitu 36\% dapat dijelaskan oleh variabel lain diluar model penelitian. Untuk koefisien determinasi (adjusted $R$ Square) pada variabel upaya pengurangan risiko infeksi adalah 0,634 atau 63,4\%. Hal ini berarti $63,4 \%$ variabel upaya pengurangan risiko infeksi dapat dijelaskan oleh komunikasi, kerjasama tim dan kepemimpinan, sedangkan sisanya yaitu $36,6 \%$ dapat dijelaskan oleh variabel lain diluar model penelitian. Secara keseluruhan, hasil pengujian hipotesis dapat dilihat pada tabel berikut:

Tabel 6

Ringkasan Hasil Pengujian Hipotesis Pengaruh Langsung

\begin{tabular}{|c|c|c|}
\hline Kode & Hipotesis & Hasil \\
\hline H1 & $\begin{array}{l}\text { Komunikasi } \\
\text { berpengaruh } \\
\text { langsung terhadap } \\
\text { upaya pengurangan } \\
\text { risiko infeksi }\end{array}$ & Diterima \\
\hline $\mathrm{H} 2$ & $\begin{array}{l}\text { Kerjasama tim } \\
\text { berpengaruh } \\
\text { langsung terhadap } \\
\text { upaya pengurangan } \\
\text { risiko infeksi }\end{array}$ & Diterima \\
\hline H3 & $\begin{array}{l}\text { kepemimpinan } \\
\text { berpengaruh } \\
\text { langsung dengan }\end{array}$ & Diterima \\
\hline
\end{tabular}




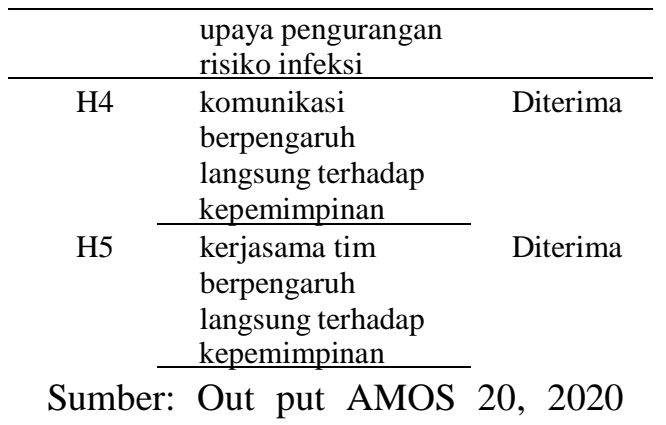

Pengujian hipotesis mediasi

dilakukan dengan prosedur yang dikembangkan oleh (Sobel, 1982) dan dikenal dengan uji Sobel (Sobel test). Uji sobel dilakukan dengan cara menguji kekuatan pengaruh tidak langsung variable independen (X) ke variabel dependen $(\mathrm{Y})$ melalui variabel mediasi (Z). Berdasarkan hasil uji Sobel, pengaruh tidak langsung komunikasi terhadap upaya pengurangan risiko infeksi memiliki nilai yang tidak signifikan, ini dapat dilihat dari nilai z $0,359<1,96$ dan $\mathrm{p}$ value $0,72>0,05$. Dengan demikian dapat disimpulkan bahwa kepemimpinan tidak memediasi komunikasi terhadap upaya pengurangan risiko infeksi di unit Rawat Inap RS X Pulomas. Pengaruh tidak langsung Kerjasama tim terhadap upaya pengurangan risiko infeksi juga memiliki nilai yang tidak signifikan, ini dapat dilihat dari nilai z $0,357<1,96$ dan $\mathrm{p}$ value $0,72>0,05$. Dengan demikian dapat disimpulkan bahwa disimpulkan bahwa kerjasama tim tidak memediasi komunikasi terhadap upaya pengurangan risiko infeksi di unit Rawat Inap RS X Pulomas.

\section{B. Pembahasan}

1. Pengaruh komunikasi terhadap upaya pengurangan risiko infeksi

Berdasarkan pembuktian empirik, maka temuan penelitian ini menunjukkan bahwa komunikasi merupakan salah satu variabel yang sangat penting dan berpengaruh langsung terhadap variabel upaya pengurangan risiko infeksi. Kondisi di lapangan dalam penelitian ini menunjukkan bahwa komunikasi antar perawat maupun komunikasi antara kepala ruangan dan anak buah di unit rawat inap RS X Pulomas sudah berjalan dengan sangat baik. Upaya pengurangan risiko infeksi di unit rawat inap RS X Pulomas juga sudah berjalan dengan baik sekali. Dari pengujian hasil penelitian, didapatkan variabel komunikasi berpengaruh signifikan terhadap variabel upaya pengurangan risiko infeksi. Berhasilnya upaya pengurangan infeksi tidak terlepas dari komunikasi yang baik antar kepala ruangan ke staf perawat ataupun antar perawat di unit rawat inap. Di unit rawat inap $\mathrm{RS} X$ Pulomas kepala ruangan memberikan umpan balik positif apabila ada kejadian terkait keselamatan pasien yang dilaporkan dan adanya diskusi terkait bagaimana cara mencegah terjadinya kejadian yang tidak diharapkan, sehingga keselamatan pasien dapat menjadi prioritas terutama dalam upaya pengurangan risiko infeksi di era pandemic covid-19. Hal ini sesuai dengan pendapat (C. Liu et al., 2020) yang menyatakan bahwa dalam era pandemi covid19 komunikasi yang efektif harus menjadi prioritas dalam meningkatkan standar pelayanan di RS. Hasil penelitian ini juga didukung oleh penelitian yang dilakukan oleh (Ong et al., 2014) yang menggarisbawahi pentingnya komunikasi yang efektif dalam memastikan kepatuhan dengan 
tindakan pencegahan pengendalian infeksi selama transisi perawatan.

Berdasarkan perhitungan koefisien jalur pengaruh komunikasi terhadap upaya pengurangan risiko infeksi dalam penelitian ini, diperoleh hasil koefisien jalur sebesar 0,162 dan $\mathrm{P}$ value 0,008 . Karena $\mathrm{p}$ value $<0,05$, maka koefisien jalur signifikan, berarti komunikasi berpengaruh langsung positif terhadap upaya pengurangan risiko infeksi. Dengan demikian, hasil penelitian ini mendukung teori yang disampaikan oleh (Walshe \& Boaden, 2005).

2. Pengaruh kerjasama tim terhadap upaya pengurangan risiko infeksi

Berdasarkan pembuktian empirik, maka temuan penelitian ini menunjukkan bahwa kerjasama tim merupakan salah satu variabel yang sangat penting dan paling berpengaruh langsung terhadap variabel upaya pengurangan risiko infeksi.

Kondisi di lapangan dalam penelitian ini menunjukkan bahwa upaya pengurangan risiko infeksi di unit rawat inap RS X Pulomas sudah berjalan baik sekali, hasil ini tidak terlepas dari peran kerjasama tim yang juga berjalan dengan sangat baik. Pada analisis deskriptif ditemukan bahwa para perawat di unit rawat inap selalu mendukung rumah sakit dalam mengurangi risiko infeksi dan masingmasing individu mampu berkoordinasi dengan baik untuk mewujudkan pelayanan pasien yang sesuai dengan prosedur keselamatan pasien. Hal ini sesuai dengan hipotesis yang menyatakan bahwa kerjasama tim berpengaruh terhadap upaya pengurangan risiko infeksi yang dikembangkan dari hasil penelitian (Andonian et al., 2019) dimana kerjasama tim secara signifikan mengurangi jumlah kontaminasi terhadap petugas Kesehatan. Hasil penelitian ini didukung oleh pendapat dari (Terry, 2020) dalam Nipawin Journal, Canada, yang menyatakan bahwa Kerjasama tim pada suatu unit sangat penting dalam menghadapi coronavirus. Menurut (Boev \& Xia, 2015) juga mendukung hal ini dengan penelitiannya yang menyatakan bahwa kolaborasi perawat-dokter secara signifikan berhubungan dengan infeksi terkait pelayanan kesehatan Namun hal ini tidak sesuai dengan penelitian yang dilakukan oleh (Arifiana Tri Wulandari et al., 2017) yang menyatakan bahwa kerjasama tim dalam budaya organisasi tidak memiliki hubungan yang signifikan dengan implementasi keselamatan pasien.

Berdasarkan perhitungan koefisien jalur pengaruh kerjasama tim terhadap upaya pengurangan risiko infeksi dalam penelitian ini, diperoleh hasil koefisien jalur sebesar 0,522 dan $\mathrm{P}$ value $<0,05$. Karena $\mathrm{p}$ value $<0,05$, maka koefisien jalur signifikan, berarti kerjasama tim berpengaruh langsung positif terhadap upaya pengurangan risiko infeksi. Dengan demikian, hasil penelitian ini mendukung teori yang disampaikan oleh (Katzenbach, 1993).

3. Pengaruh kepemimpinan terhadap upaya pengurangan risiko infeksi

Temuan penelitian ini menunjukkan bahwa kepemimpinan merupakan salah satu variabel yang berpengaruh langsung terhadap variabel upaya pengurangan risiko infeksi.

Kondisi di lapangan dalam penelitian ini menunjukkan bahwa kepemimpinan kepala ruanagan di unit 
rawat inap RS X Pulomas sudah berjalan dengan sangat baik. Menurut penggolongan gaya kepemimpinan, kepemimpinan di unit rawat inap RS X Pulomas memiliki gaya kepemimpinan transformasional karena memenuhi empat faktor untuk menuju kepemimpinan tranformasioal (Bass \& Bass Bernard, 1985) yaitu Idealized influence dimana kepala ruangan mampu menciptakan suasana kerja yang kondusif dan aman sehingga dapat dipercaya, Inspirational motivation dimana kepala ruangan selalu memberikan bimbingan dan dorongan kepada staf terkait penerapan tindakan mengurangi risiko infeksi, Intellectual Stimulation dimana kepala ruangan memberikan kebebasan kepada bawahannya yang ingin memberikan pendapat terkait issue penerapan keselamatan pasien dalam upaya pengurangan risiko infeksi, pemimpin dapat menumbuhkan kreativitas dan inovasi pada karyawan dan Individual consideration dimana kepala ruangan secara rutin mengadakan pelatihan atau sosialisasi terkait upaya pengurangan risiko infeksi di unit rawat inap.Berdasarkan analisa deskriptif, keempat faktor tersebut memiliki nilai naik sekali. Menurut (Northouse et al., 2001) menyimpulkan, gaya kepemimpinan transformasional lebih efektif dan amat menguntungkan perusahaan. Para pemimpin jenis ini memperhatikan dan terlibat langsung dalam proses termasuk membantu para anggota kelompok untuk berhasil menyelesaikan tugas mereka, dimana salah satu tugas mereka adalah melaksanakan upaya pengurangan risiko infeksi di unit rawat inap. Upaya pengurangan risiko infeksi di unit rawat inap RS X Pulomas berdasarkan penelitian juga berjalan dengan sangat baik. Hasil penelitian (Flandoli, 2011) yang menyatakan bahwa Kepemimpinan berperan penting dalam kegiatan pencegahan infeksi. Perilaku pemimpin yang sukses bisa diadopsi oleh orang lain dan berusaha mencegah HAI. Penelitian Saint et al juga didukung oleh (Boamah et al., 2017) yang pada penelitiannya menghasilkan kepemimpinan transformasional secara signifikan menurunkan angka kejadian tidak diharapkan.

\begin{tabular}{lrr}
\multicolumn{2}{c}{ Berdasarkan } & perhitungan \\
koefisien jalur & pengaruh \\
kepemimpinan terhadap & upaya \\
pengurangan risiko infeksi & dalam \\
penelitian ini, diperoleh hasil &
\end{tabular}
koefisien jalur sebesar $-0,151$ dan $\mathrm{P}$ value $<0,05$. Karena $p$ value $<0,05$, maka koefisien jalur signifikan, berarti kepemimpinan berpengaruh langsung negatif terhadap upaya pengurangan risiko infeksi. Dengan demikian, hasil penelitian ini mendukung teori yang disampaikan oleh (Bass \& Bass Bernard, 1985).

4. Pengaruh komunikasi terhadap kepemimpinan

Berdasarkan pembuktian empirik, maka temuan penelitian ini menunjukkan bahwa komunikasi merupakan salah satu variabel yang sangat penting dan berpengaruh langsung terhadap variabel kepemimpinan. Kondisi di lapangan dalam penelitian ini menunjukkan bahwa komunikasi antar perawat maupun komunikasi antara kepala ruangan dan anak buah di unit rawat inap RS X Pulomas sudah berjalan dengan sangat baik. Komunikasi menjadi efektif salah satunya dipengaruhi oleh faktor 
kepemimpinan, dimana kepala ruangan memberikan umpan balik positif kepada perawat di ruangan apabila ada suatu kejadian yang dilaporkan, proses hand over yang baik dimana informasi perawatan pasien yang penting selalu disampaikan dan adanya diskusi pembahasan masalah dalam mencara jalan keluar. Selain itu kepala ruangan memberikan kebebasan dalam menyampaikan pendapat dan memberi usulan kebijakan. Dimana hal ini menunjukkan kepemimpinan yang selama ini berjalan mampu membentuk komunikasi yang efektif.

Hal ini sesuai dengan hipotesis yang menyatakan bahwa komunikasi berpengaruh terhadap kepemimpian yang dikembangkan dari hasil penelitian (Cullen et al., 2014) yang menemukan bahwa pemimpin dengan komunikasi yang baik akan memiliki dampak positif bagi organisasi. Menurut (Choi et al., 2017) juga mendukung hal ini dengan hasil penelitiannya dimana pendidikan kepemimpinan secara signifikan berkorelasi positif dengan komunikasi organisasi.

Berdasarkan perhitungan koefisien jalur pengaruh komunikasi terhadap kepemimpinan dalam penelitian ini, diperoleh hasil koefisien jalur sebesar 0,889 dan $\mathrm{P}$ value $<0,05$. Karena $p$ value $<0,05$, maka koefisien jalur signifikan, berarti komunikasi berpengaruh langsung positif terhadap kepemimpinan. Dengan demikian, hasil penelitian ini mendukung teori yang disampaikan oleh (Walshe \& Boaden, 2005).

5. Pengaruh kerjasama tim terhadap kepemimpinan

Berdasarkan pembuktian empirik, maka temuan penelitian ini menunjukkan bahwa kerjasama tim merupakan salah satu variabel yang sangat penting dan berpengaruh langsung terhadap variabel kepemimpinan.

Kondisi di lapangan dalam penelitian ini menunjukkan bahwa kerjasama tim antar perawat di unit rawat inap $\mathrm{RS} X$ Pulomas sudah berjalan dengan sangat baik. bertambah kuat atau solidnya kerjasama tim ini salah satunya dipengaruhi oleh faktor kepemimpinan, dimana kepala ruangan yang selalu berkoordinasi dengan perawat di ruangan terkait upaya pengurangan risiko infeksi di rumah sakit. Kepala ruangan memberikan kebebasan dalam menyampaikan pendapat mendelegasikan wewenang dengan baik kepada bawahannya. Dimana hal ini menunjukkan kepemimpinan yang selama ini berjalan mampu membentuk kerjasama tim yang efektif. Hasil penelitian (Choi et al., 2017) yang menemukan bahwa kepemimpinan secara signifikan berkorelasi positif dengan efektivitas tim dan komunikasi organisasi.

Berdasarkan perhitungan koefisien jalur pengaruh kerjasama tim terhadap kepemimpinan dalam penelitian ini, diperoleh hasil koefisien jalur sebesar 0.613 dan $\mathrm{P}$ value $<0,05$. Karena $p$ value $<0,05$, maka koefisien jalur signifikan, berarti kerjasama tim berpengaruh langsung positif terhadap kepemimpinan. Dengan demikian, hasil penelitian ini mendukung teori yang disampaikan oleh (Kron \& Chiu, 1981).

6. Pengaruh komunikasi dan kerjasama tim dengan dimediasi kepemimpinan terhadap upaya pengurangan risiko infeksi 
Berdasarkan pembuktian empirik, maka temuan penelitian ini menunjukkan bahwa komunikasi, kerjasama tim dan kepemimpinan bersama-sama memiliki pengaruh terhadap upaya pengurangan risiko infeksi, namun kepemimpinan tidak memediasi antara komunikasi dan kerjasama tim terhadap upaya pengurangan risiko infeksi.

Kondisi di lapangan dalam penelitian ini menunjukkan bahwa upaya pengurangan risiko infeksi di unit rawat inap RS X Pulomas sudah berjalan dengan baik. Komunikasi dan kerjasama tim merupakan faktor yang berpengaruh dalam meningkatkan upaya pengurangan risiko infeksi. Kepala ruangan selama masa pandemi Covid-19 telah terjadi rotasi yang relatif singkat waktunya, yaitu dalam waktu 6 bulan telah dilakukan rotasi kepala ruangan sebanyak 2 kali. Dari pengujian hasil penelitian, pada hasil uji Sobel, didapatkan bahwa variabel kepemimpinan tidak memediasi antara komunikasi dan kerjasama tim terhadap variabel upaya pengurangan risiko infeksi. Beberapa faktor yangdiduga mengakibatkan variabel kepemimpinan menjadi tidak dapat memediasi antara komunikasi dan kerjasama tim terhadap pengurangan risiko infeksi adalah rotasi kepala ruang perawatan yang relatif singkat waktunya, yaitu dalam waktu 6 bulan telah dilakukan rotasi kepala ruangan sebanyak 2x, hal ini dapat mengakibatkan peran kepemimpinan dari kepala ruangan dalam ruang perawatan menjadi tidak terlihat Faktor lain yang kemungkinan dapat menyebabkan kepemimpinan tidak dapat memediasi adalah peran kepemimpinan yang merupakan bagian dari kerjasama tim, sehingga kepemimpinan bukan merupakan faktor mediasi, melainkan merupakan dimensi dari kerjasama tim itu sendiri. Terkait kepemimpinan sebagai variabel mediasi dari komunikasi dan kerjasama tim terhadap upaya pengurangan risiko infeksi, peneliti belum menemukan penelitian yang serupa pada penelitian sebelumnya. Namun penelitian terkait hubungan antara ketiganya sudah dilakukan oleh (van Zandwijk et al., 2013) yang menyatakan kepemimpinan, komunikasi dan kerjasama tim bersama-sama berpengaruh terhadap keselamatan pasien dan mutu RS. (Arifiana Tri Wulandari et al., 2017) juga menyatakan kepemimpinan bersama dengan komunikasi memiliki pengaruh dalam implementasi keselamatan pasien. Penelitian (Arifiana Tri Wulandari et al., 2017) terkait hal ini didukung oleh penelitian yang dilakukan (Cullen et al., 2014) dimana keterampilan kepemimpinan dan komunikasi memiliki dampak positif pada perilaku tim perawat dalam organisasi

Berdasarkan perhitungan koefisien jalur pengaruh kerjasama tim terhadap kepemimpinan dalam penelitian ini, diperoleh hasil $\mathrm{P}$ value 0,72 . Karena $\mathrm{p}$ value $>0,05$, maka koefisien jalur tidak signifikan, berarti kepemimpinan tidak dapat memediasi komunikasi dan kerjasama tim terhadap upaya pengurangan risiko infeksi.

\section{Kesimpulan}

Berdasarkan analisis hasil penelitian, maka didapatkan komunikasi, kerjasama tim dan kepemimpinan memiliki pengaruh langsung yang signifikan terhadap upaya pengurangan risiko infeksi di unit rawat inap RS X Pulomas. Komunikasi dan Kerjasama 
tim sama-sama berpengaruh terhadap kepemimpinan di unit rawat inap $\mathrm{RS} X$ Pulomas. Dimana kepemimpinan yang baik harus didukung oleh komunikasi dan kerjasama tim yang baik. Hal ini sesuai dengan penelitian Choi et al (2017) yang menemukan bahwa kepemimpinan secara signifikan berkorelasi positif dengan efektivitas tim dan komunikasi organisasi Dengan demikian hipotesis pengaruh komunikasi terhadap kepemimpinan dan kerjasama tim terhadap kepemimpinan (hipotesis keempat dan hipotesis kelima) diterima dan didukung oleh data empiris. Komunikasi dan kerjasama tim berpengaruh signifikan terhadap upaya pengurangan risiko infeksi di unit rawat inap RS X Pulomas. Ini berarti dalam meminimalisir risiko infeksi di unit rawat inap RS X Pulomas, dibutuhkan komunikasi dan kerjasama tim yang baik. Factor Kerjasama tim merupakan variabel yang paling berpengaruh dalam upaya pengurangan risiko infeksi di unit rawat inap RS X Pulomas. Hal ini sesuai dengan penelitian yang dilakukan oleh Andonian et al (2019) yang menyatakan bahwa Kerjasama tim secara signifikan mengurangi jumlah kontaminasi terhadap petugas kesehatan. Dalam penelitian ini juga didapatkan bahwa kepemimpinan tidak memediasi antara komunikasi dan kerjasama tim terhadap upaya pengurangan risiko infeksi di unit rawat inap RS X Pulomas.

\section{BIBLIOGRAFI}

Andonian, J., Kazi, S., Therkorn, J., Benishek, L., Billman, C., Schiffhauer, M., Nowakowski, E., Osei, P., Gurses, A. P., \& Hsu, Y.-J. (2019). Effect Of An Intervention Package And Teamwork Training To Prevent Healthcare Personnel Self-Contamination During Personal Protective Equipment Doffing. Clinical Infectious Diseases, 69(Supplement_3), S248-S255. Google Scholar
Arifiana Tri Wulandari, W., Muhammad Anshoruddin, A., Intan Wahyuni, I., Putri Agustia, T., Waliyudin Amin, A., Randy Maulana Yusuf Efendi, R., Putri Astiti, P., Dian Puspitasari, D., \& Fridawati Luthfi Kurnia, F. (2017). Laporan Pelaksanaan Kkn Reguler Uad Periode Lxi Ta. 2016/2017 Unit Ii. A. 1 Dusun Deplongan Desa Wates Kec. Getasan Kab. Semarang Provinsi Jawa Tengah. Laporan Pelaksanaan Kkn Reguler Uad Periode Lxi Ta. 2016/2017 Unit Ii. A. 1 Dusun Deplongan Desa Wates Kec. Getasan Kab. Semarang Provinsi Jawa Tengah. Google Scholar

Bass, B. M., \& Bass Bernard, M. (1985). Leadership And Performance Beyond Expectations. Google Scholar

Boamah, S. A., Read, E. A., \& Spence Laschinger, H. K. (2017). Factors Influencing New Graduate Nurse Burnout Development, Job Satisfaction And Patient Care Quality: A TimeLagged Study. Journal of Advanced Nursing, 73(5), 1182-1195. Google Scholar

Boev, C., \& Xia, Y. (2015). Nurse-Physician Collaboration And Hospital-Acquired Infections In Critical Care. Critical Care Nurse, 35(2), 66-72. Google Scholar

Choi, S., Attri, P., Lee, I., Oh, J., Yun, J.-H., Park, J. H., Choi, E. H., \& Lee, W. (2017). Structural And Functional Analysis Of Lysozyme After Treatment With Dielectric Barrier Discharge Plasma And Atmospheric Pressure Plasma Jet. Scientific Reports, 7(1), 110. Google Scholar

Cullen, A. E., Zunszain, P. A., Dickson, H., Roberts, R. E., Fisher, H. L., Pariante, C. M., \& Laurens, K. R. (2014). Cortisol Awakening Response And Diurnal Cortisol Among Children At Elevated Risk For Schizophrenia: Relationship To Psychosocial Stress And Cognition. Psychoneuroendocrinology, 46, 1-13. Google Scholar 
Ferdinand, R. F. (2008). Validity Of The $\mathrm{Cbcl} / \mathrm{Ysr}$ Dsm-Iv Scales Anxiety Problems And Affective Problems. Journal Of Anxiety Disorders, 22(1), 126-134. Google Scholar

Flandoli, F. (2011). Random Perturbation Of Pdes And Fluid Dynamic Models: École D'été De Probabilités De Saint-Flour $X l-2010$ (Vol. 2015). Springer Science \& Business Media. Google Scholar

Katzenbach, J. R. (1993). Douglas K. Smith. The Wisdom Of Teams: Creating The High Performance Organization. Google Scholar

Kemenkes, R. I. (2016). Buku Kesehatan Ibu Dan Anak. In Kementrian Kesehat Ri Dan Jica Jakarta. Google Scholar

Kron, R. G., \& Chiu, L.-T. (1981). Stars With Zero Prper Motion And The Number Of Faint Qsos. Publications of The Astronomical Society of The Pacific, 93(554), 397. Google Scholar

Liu, C., Frank, Q. Y., Newman, J. D., Szczupak, D., Tian, X., Yen, C. C.-C., Majka, P., Glen, D., Rosa, M. G. P., \& Leopold, D. A. (2020). A Resource For The Detailed 3d Mapping Of White Matter Pathways In The Marmoset Brain. Nature Neuroscience, 23(2), 271-280. Google Scholar

Liu, Y., Wang, H., Chen, J., Zhang, X., Yue, X., Ke, J., Wang, B., \& Peng, C. (2020). Emergency Management Of Nursing Human Resources And Supplies To Respond To Coronavirus Disease 2019 Epidemic. International Journal of Nursing Sciences, 7(2), 135-138. Google Scholar

Mouaze, D., Chanson, H., \& Simon, B. (2010). Field Measurements In The Tidal Bore Of The Sélune River In The Bay Of Mont Saint Michel (September 2010). Google Scholar
Murray, M., Bullard, M., \& Grafstein, E. (2004). Revisions To The Canadian Emergency Department Triage And Acuity Scale Implementation Guidelines. Canadian Journal of Emergency Medicine, 6(6), 421-427. Google Scholar

Northouse, L., Templin, T., \& Mood, D. (2001). Couples' Adjustment To Breast Disease During The First Year Following Diagnosis. Journal of Behavioral Medicine, 24(2), 115-136. Google Scholar

Ong, Y. H., Chua, A. S. M., Fukushima, T., Ngoh, G. C., Shoji, T., \& Michinaka, A. (2014). High-Temperature Ebpr Process: The Performance, Analysis Of Paos And Gaos And The Fine-Scale Population Study Of Candidatus "Accumulibacter Phosphatis." Water Research, 64, 102112. Google Scholar

Sobel, M. E. (1982). Asymptotic Confidence Intervals For Indirect Effects In Structural Equation Models. Sociological Methodology, 13, 290-312. Google Scholar

Susilo, A., Rumende, C. M., Pitoyo, C. W., Santoso, W. D., Yulianti, M., Herikurniawan, H., Sinto, R., Singh, G., Nainggolan, L., Nelwan, E. J., Chen, L. K., Widhani, A., Wijaya, E., Wicaksana, B., Maksum, M., Annisa, F., Jasirwan, C. O. M., \& Yunihastuti, E. (2020). Coronavirus Disease 2019: Tinjauan Literatur Terkini. Jurnal Penyakit Dalam Indonesia. Google Scholar

Terry, L. (2020). When Art Imitates Life: Exploring The Scientific And Anatomical Practices Of Artists From Hellenism To The Baroque. Google Scholar

Van Zandwijk, N., Clarke, C., Henderson, D., Musk, A. W., Fong, K., Nowak, A., Loneragan, R., Mccaughan, B., Boyer, M., \& Feigen, M. (2013). Guidelines For The Diagnosis And Treatment of Malignant Pleural Mesothelioma. 
Cintya Elvira Purba, Natsir Nugroho dan Ratna Indrawati

Journal Of Thoracic Disease, 5(6), E254.

Google Scholar

Walshe, K., \& Boaden, R. (2005). Patient

Safety: Research Into Practice. Mcgraw-

Hill Education (Uk). Google Scholar

\section{Copyright holder:}

Cintya Elvira Purba, Natsir Nugroho dan Ratna Indrawati (2021)

First publication right:

Jurnal Health Sains

This article is licensed under:

(c) (i) (? 